\title{
PROSES PRODUKSI TRIASETIN DARI GLISEROL DENGAN KATALIS ASAM SULFAT
}

\author{
Widayat ${ }^{1,2 *}$, Hantoro Satriadi' ${ }^{1}$ Abdullah ${ }^{1,2}$, Ika Windrianto K. Handono1 \\ 1 Jurusan Teknik Kimia, Fakultas Teknik, Universitas Diponegoro \\ ${ }^{2} \mathrm{C}$-Biomass and Renewable Energy (CBIORE) \\ Jalan Prof. Soedarto, Kampus Tembalang, Semarang 50239 \\ Email: yayat_99@yahoo.com
}

\begin{abstract}
Abstrak
Gliserol dapat dihasilkan dari proses produksi biodiesel dari proses transesterifikasi. Gliserol dari proses ini, belum dimanfaatkan secara maksimal sebagai bahan baku maupun sebagai produk jadi. Triasetin atau gliserol triasetin merupakan produk reaksi esterifikasi gliserol dengan asam asetat. Kegunaan triasetin cukup banyak baik untuk keperluan bahan pangan maupun non pangan. Penelitian ini bertujuan untuk mempelajari pengaruh temperatur dan perbandingan reaktan terhadap konversi gliserol dalam proses produksi triasetin. Percobaan dilakukan dengan proses curah, dimana volume total gliserol dan asam asetat sebesar $600 \mathrm{~mL}$, kecepatan pengadukan $100 \mathrm{rpm}$ dan katalis asam sulfat adalah $5 \%$-b gliserol. Hasil analisis kualitatif dengan alat FTIR menunjukkan adanya produk triasetin, dimana kesesuaian dengan bahan standar triasetin cukup tinggi. Peningkatan perbandingan gliserol dengan asam asetat akan meningkatkan konversi gliserol. Demikian juga dengan peningkatan temperatur juga akan meningkatkan konversi gliserol. Hasil yang terbaik diperoleh pada perbandingan mol pereaksi gliserol dan asam asetat $1: 7$ temperatur $120{ }^{\circ} \mathrm{C}$, waktu 50 menit dengan nilai konversi sebesar 67,6\% dan selektivitas sebesar $25 \%$.
\end{abstract}

Kata kunci: gliserol, asam asetat, esterifikasi, triasetin, konversi gliserol

\begin{abstract}
TRIACETIN PRODUCTION PROCESS FROM GLYCEROL USING SULFURIC ACID AS CATALYST. Glycerol can be produced from biodiesel production process with transesterification reaction. Glycerol of this reaction, not fully utilized as raw materials or as chemial products. Triacetate is a product of the esterification reaction of glycerol with acetic acid. Triacetate can be used for food and non-food. The objective of this study was to study the effect of temperature and the ratio of reactants on glycerol conversion on triacetate production process. The experiments were carried in batch process and total volume of glycerol and acetic acid $600 \mathrm{~mL}$, stirring speed of $100 \mathrm{rpm}$ and catalyst of sulphuric acid was $5 \%$-w glycerol based. The results of the qualitative analysis by means of FTIR confirmed there is Triacetate as product. Increasing of ratio molar of glycerol to acetic acid increased of glycerol conversion. The similar result obtained for temperature. The glycerol conversion was $67.6 \%$ and selectivity of triacetate $25 \%$, where obtained using the reaction condition: mole ratio of glycerol to acetic acid $1: 7$, temperature $120{ }^{\circ} \mathrm{C}$ and 50 minutes.
\end{abstract}

Keywords: glycerol, acetate acid, esterification, triacetin, glycerol conversion 


\section{PENDAHULUAN}

$\begin{array}{rrrr}\text { Gliserol adalah } & \text { produk } & \text { samping } \\ \text { produksi biodiesel } & \text { dari } & \text { reaksi }\end{array}$ transesterifikasi. Gliserol merupakan senyawa alkohol dengan gugus hidroksil berjumlah 3 dan dikenal dengan nama 1,2,3-propanatriol. Gliserol berbentuk cairan kental tidak berwarna, tidak berbau, dan memiliki rasa manis (Pagliaro dan Michele, 2008). Gliserol bila diesterifikasi dengan asam asetat akan membentuk triasetin, atau gliserol triasetin. Kegunaan triasetin sangat banyak baik untuk keperluan bahan pangan maupun non pangan. Untuk bahan pangan, triasetin dapat digunakan sebagai bahan aroma pada permen (gula-gula), minuman dari susu, minuman ringan, dan permen karet. Kegunaan dalam bidang non pangan, triasetin dapat digunakan untuk pelarut pada parfum, tinta cetak, pelarut pada aroma, pelarut, plastisizer, dan sebagai bahan aditif bahan bakar untuk mengurangi knocking pada mesin mobil (Rahmat dkk., 2010; Khayoon dan Hameed, 2011). Dengan potensi sebagai bahan aditif dalam peningkatan nilai oktan bahan bakar (bensin), senyawa triasetin sangat berpotensi untuk dikembangkan, apalagi bahan baku yang digunakan berasal dari limbah biodiesel.

Triasetin dapat diproduksi dari reaksi gliserol dan asam asetat menggunakan katalis yang bersifat asam. Katalis yang digunakan dapat berbentuk homogen maupun heterogen. Secara teoritik, setiap mol gliserol membutuhkan $3 \mathrm{~mol}$ asam asetat. Reaksi diikuti pelepasan air seperti pada Gambar 1.

$$
\text { Pembuatan triasetin dengan }
$$

mereaksikan gliserol dan asam asetat telah dilakukan oleh peneliti sebelumnya. Gelosa dkk. (2003) mempelajari reaksi gliserol dengan asam asetat dengan katalis resin Amberlyst-15. Konversi tertinggi diperoleh pada temperatur $373 \mathrm{~K}$ dan perbandingan pereaksi 3,9 gmol asam asetat/gmol gliserol, yaitu sebesar 50\%. Liao dkk. (2009) mereaksikan gliserol dan asam asetat dengan katalis zeolit dan Amberlyst-35. Reaksi dilakukan pada perbandingan molar gliserol terhadap asetat sebesar 1:9 selama 4 jam pada temperatur $105{ }^{\circ} \mathrm{C}$, dengan massa katalis sebesar 0,5 g. Konversi yang diperoleh adalah sebesar $100 \%$, dengan selektivitas $25 \%$. Penggunaan katalis Amberlyst-35 memberikan hasil yang lebih baik dbandingkan dengan katalis zeolit. Jagadeeswaraiah dkk. (2010) mereaksikan gliserol dengan asam asetat dengan perbandingan molar 1:5 selama 4 jam pada temperatur $120{ }^{\circ} \mathrm{C}$, dan dengan massa katalis $0,2 \mathrm{~g} \mathrm{TPA} / \mathrm{Cs}_{2}-\mathrm{ZrO}_{2}$. Konversi yang diperoleh adalah sebesar $93 \%$, dengan selektivitas $17 \%$. Reddy dkk. (2010) juga melakukan esterifikasi gliserol dengan asam asetat, dengan bantuan katalis $\mathrm{ZrO}_{2}$. Kondisi operasi yang digunakan adalah perbandingan molar pereaksi 1:6, waktu operasi 3 jam dan temperatur 393 K. Penelitian Reddy dkk. (2010) tersebut mempelajari konsentrasi dan jenis katalis, dimana diperoleh konversi pada katalis $\mathrm{ZrO}_{2}$ sebesar $86 \%, \mathrm{TiO}_{2}-\mathrm{ZrO}_{2}$ sebesar $93 \%$, $\mathrm{WOx} / \mathrm{TiO}_{2}-\mathrm{ZrO}_{2}$ sebesar $100 \%$ dan $\mathrm{MoOx} / \mathrm{TiO}_{2}-\mathrm{ZrO}_{2}$ sebesar $100 \%$.

Nuryoto dkk. (2010) melakukan esterifikasi gliserol dan asam asetat dengan katalis resin Indion 225-Na pada temperatur 343K dan kecepatan pengadukan $1000 \mathrm{rpm}$. Konversi tertinggi diperoleh pada perbandingan pereaksi 7 gmol asam asetat/gmol gliserol dan konsentrasi katalis $3 \%$ berat asam asetat, yaitu sebesar $40,7 \%$. Ferreira dkk. (2009) melakukan esterifikasi gliserol dan asam asetat dengan katalis NaUSY Zeolite, dan memperoleh konversi sebesar $14 \%$ dan selektivitas triasetin sebesar $1 \%$.

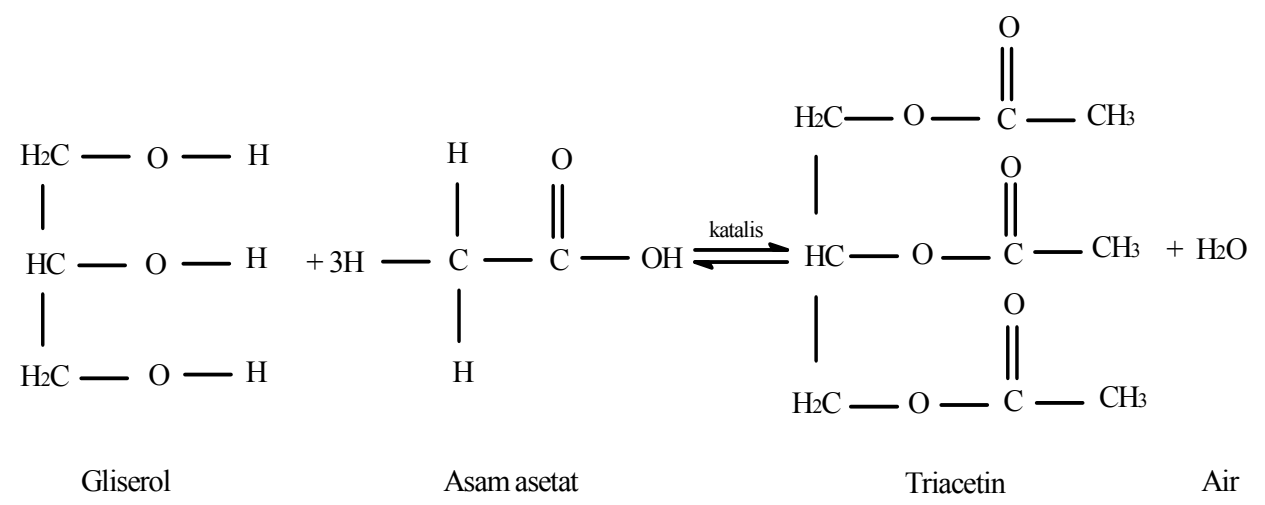

Gambar 1. Reaksi pembentukan triasetin 
Ferreira dkk. (2011) mereaksikan gliserol dengan asam asetat dengan perbandingan molar 1:16 selama 3 jam pada temperatur $120^{\circ} \mathrm{C}$ menggunakan katalis asam dodekatungstofosfat sebanyak $0,2 \mathrm{~g}$, dan memperoleh konversi sebesar $86 \%$ dengan selektivitas $11 \%$. Peneliti-peneliti tersebut umumnya menggunakan katalis heterogen, demikian juga penelitian yang lain seperti Balaraju dkk. (2010), serta Khayoon dan Hameed (2011).

Penggunaan asam sulfat sebagai katalis untuk pembuatan triasetin belum banyak diteliti. Asam sulfat selain bersifat sebagai katalis juga dapat menyerap air sehingga baik digunakan sebagai katalis produksi triasetin. Dengan sifat asam sulfat yang higroskopis, diharapkan air yang dilepaskan dapat diserap sehingga reaksi dapat berjalan ke arah produk dan konversi meningkat. Proses esterifikasi merupakan reaksi dapat balik. Salah satu cara untuk mengarahkan reaksi ke produk adalah dengan membuat reaktan berlebih atau mengambil salah satu produknya. Temperatur juga berpengaruh dalam reaksi kimia, setiap peningkatan temperatur akan meningkatkan laju reaksi kimia sehingga dapat meningkatkan konversi.

Penelitian ini bertujuan untuk mempelajari pengaruh temperatur reaksi dari 80-120 ${ }^{\circ} \mathrm{C}$ dan perbandingan mol reaktan antara gliserol dan asam asetat terhadap konversi pembentukan triasetin. Hasil penelitian ini diharapkan dapat menunjukkan temperatur reaksi dan perbandingan mol reaktan antara gliserol dan asam asetat terbaik yang menghasilkan konversi pembentukan triasetin tertinggi.

\section{METODE}

\section{Alat dan Bahan}

Labu leher tiga berkapasitas 1L digunakan sebagai reaktor. Labu dilengkapi dengan pendingin balik, water bath, termometer dan pengaduk bermagnet. Bahan yang digunakan antara lain gliserol, asam asetat, asam sulfat, $\mathrm{NaOH}$ dan akuades. Gliserol yang digunakan berspesifikasi teknis dengan kadar $90 \%$ dan densitas 1,25 g/mL. Asam asetat, $\mathrm{NaOH}$ dan asam sulfat mempunyai karakteristik analitik yang diperoleh dari Merck.

\section{Prosedur}

Penelitian ini dilakukan dengan cara esterifikasi gliserol dan asam asetat dengan menggunakan katalis asam sulfat. Rancangan percobaan menggunakan metode konvensional, dengan perbandingan reaktan dan temperatur divariasikan. Volume total gliserol dan asam asetat yang digunakan sebesar $600 \mathrm{~mL}$, kecepatan pengadukan 100 rpm, katalis sebesar $5 \%$ berat gliserol, variasi temperatur reaksi $80,90,100,110,120{ }^{\circ} \mathrm{C}$. Perbandingan mol pereaksi gliserol terhadap asam asetat $1: 3 ; 1: 4 ; 1: 5 ; 1: 6 ; 1: 7$ dan waktu reaksi $0,5,10,15,20,25,35,45,55,60$ menit.

Gliserol sebanyak $170 \mathrm{~g}$ dimasukkan ke dalam labu leher tiga dan dipanaskan sampai temperatur $80{ }^{\circ} \mathrm{C}$. Asam asetat sebanyak 136 g dipanaskan dalam beaker glass sampai temperatur $80{ }^{\circ} \mathrm{C}$. Asam asetat dicampur dengan gliserol di dalam labu leher tiga. Asam asetat ditambahkan tetes demi tetes sebanyak 4,7 mL. Proses dilanjutkan dengan pengadukan sebesar $100 \mathrm{rpm}$ dan mulai dicatat sebagai waktu ke nol. Setiap 5 menit dilakukan pengambilan sampel dan dianalisis konsentrasi asam total dengan metode asidialkali metri.

\section{Analisis}

Proses analisis dilakukan secara kualitatif dan kuantitatif. Analisis kualitatif gugus fungsional menggunakan alat FTIR Thermo Nicolet Avatar 360. Konsentrasi asam sisa dianalisis dengan metode titrasi asambasa menggunakan larutan $\mathrm{NaOH} \quad 0,5 \mathrm{~N}$ sebagai titran. Asam asetat yang bereaksi dapat dihitung dari stoikiometri reaksi asam asetat dengan gliserol. Dengan demikian gliserol yang bereaksi juga dapat dihitung dengan metode yang sama. Adapun konversi gliserol dihitung dengan persamaan berikut:

$$
\begin{aligned}
& \text { Konversi gliserol } \\
& =\frac{\text { gliserol yang bereaksi }}{\text { gliserol mula }- \text { mula }} \times 100 \%
\end{aligned}
$$

\section{HASIL DAN PEMBAHASAN \\ Karakteristik Produk Triasetin}

Triasetin merupakan senyawa ester dari gugus asetat dan gugus gliseril. Keberadaan senyawa ini dalam suatu produk dapat dikenali dengan metode analisis FTIR (Fourier Transform Infrared Spectroscopy). Hasil analisis yang berupa spektrum serapan radiasi inframerah disajikan dalam Gambar 2.

Senyawa triasetin mempunyai rumus kimia $\mathrm{CH}_{3} \mathrm{COOCH}_{2} \mathrm{CH}\left(\mathrm{CH}_{3} \mathrm{COO}\right) \mathrm{CH}_{2}\left(\mathrm{CH}_{3} \mathrm{COO}\right)$ 
dan rumus bangun seperti disajikan dalam Gambar 3. Senyawa ini terdiri atas gugus ester, gugus metil serta ikatan atom karbon dengan atom karbon. Dalam analisis FTIR, gugus-gugus tersebut akan menyebabkan vibrasi, regangan maupun goyangan yang menyerap sebagian energi radiasi inframerah. Hal ini dapat dideteksi oleh fotometer, dan muncul sebagai puncak-puncak pada spektrum serapan radiasi seperti yang ditampilkan pada Gambar 2. Bilanganbilangan gelombang tempat munculnya puncak-puncak tersebut selanjutnya digunakan untuk mengidentifikasi gugusgugus fungsional yang menyebabkan kemunculan puncak-puncak tersebut. Bilangan gelombang hasil identifikasi puncakpuncak sampel produk reaksi disajikan dalam Tabel 1.

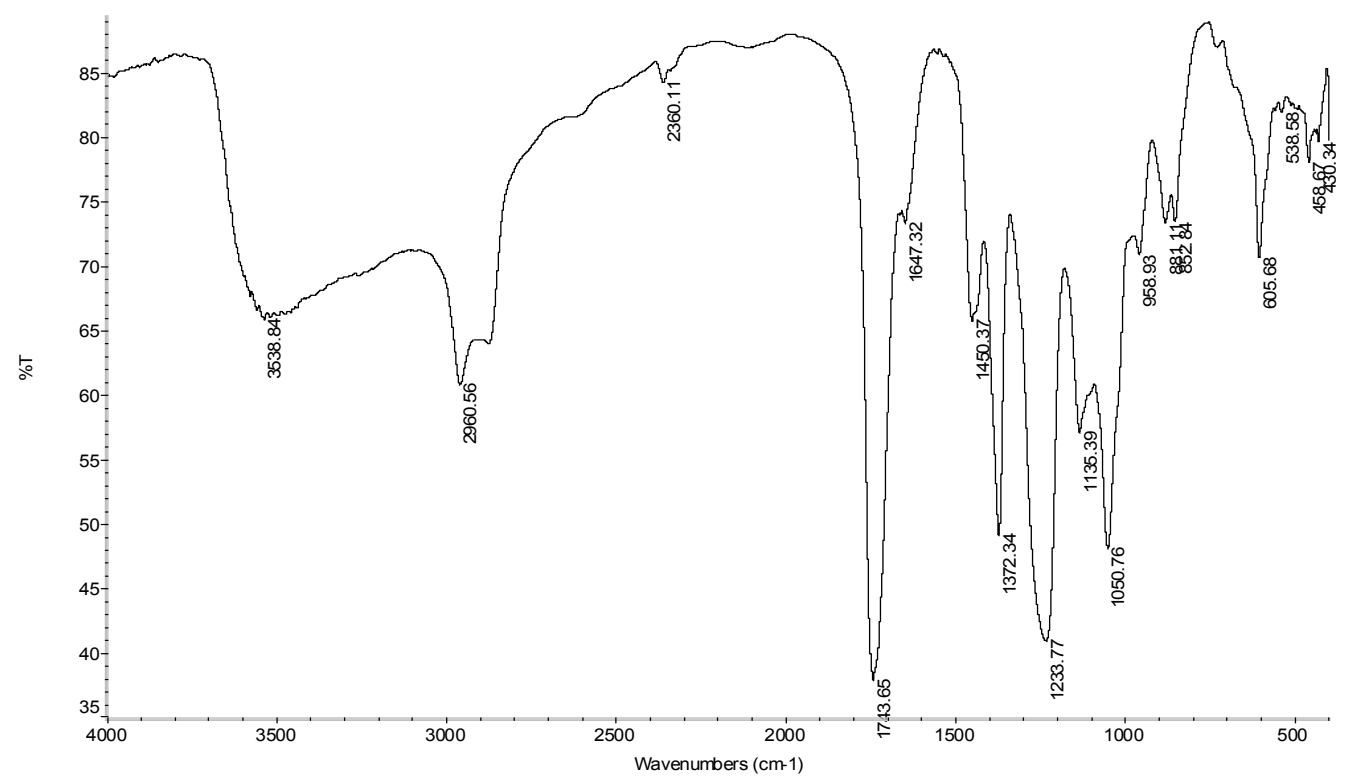

Gambar 2. Analisis kualitatif dengan FTIR dari produk triasetin<smiles>CC(=O)OCC(COC(C)=O)OC(C)=O</smiles>

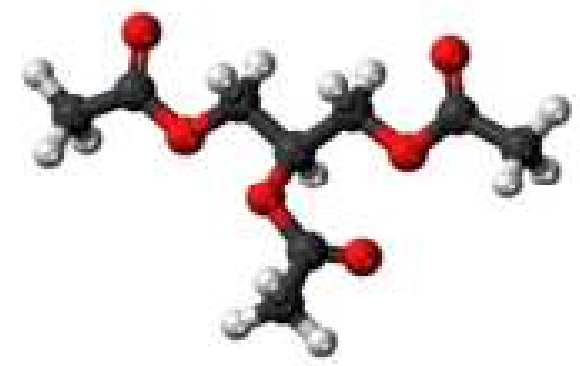

Gambar 3. Rumus bangun triasetin

Tabel 1. Bilangan Gelombang Hasil Spektra IR Sampel (Vogel, 1989)

\begin{tabular}{cccc}
\hline $\begin{array}{c}\text { Bilangan } \\
\text { gelombang }\left(\mathrm{cm}^{-1}\right)\end{array}$ & Group & $\begin{array}{c}\text { Bilangan } \\
\text { gelombang }\left(\mathrm{cm}^{-1}\right)\end{array}$ & Group \\
\hline 538,58 & $\mathrm{C}-\mathrm{Br}$ & 1233,77 & $\mathrm{C}-\mathrm{F}$ \\
605,68 & $\mathrm{C}-\mathrm{Cl}$ & 1372,34 & $\mathrm{CH}_{3^{-}},-\mathrm{CH}_{2-}$ \\
852,84 & $\mathrm{C}-\mathrm{C}$ & 1450,37 & $\mathrm{CH}_{3^{-}},-\mathrm{CH}_{2-}^{-}$ \\
881,1 & $\mathrm{C}-\mathrm{C}$ & 1647,32 & $\mathrm{C}=\mathrm{C}$ \\
958,93 & $\mathrm{C}-\mathrm{C}$ & 1743,65 & $\mathrm{C}=\mathrm{O}(\mathrm{ester})$ \\
1050,76 & $\mathrm{C}-\mathrm{F}$ & 2960,56 & $\mathrm{C}-\mathrm{H}$ (aliphatic) \\
1135,39 & $\mathrm{C}-\mathrm{F}$ & 3538,84 & $0-\mathrm{H}$ (phenolic, hydrogen \\
& & & bonding) \\
\hline
\end{tabular}


Triasetin merupakan senyawa ester, yang menghasilkan puncak-puncak serapan dalam analisis FTIR pada bilangan gelombang 1700-1750 $\mathrm{cm}^{-1}$ (Vogel, 1989). Tabel 1 menunjukkan puncak pada bilangan gelombang 1743,65 $\mathrm{cm}^{-1}$ yang tergolong dalam grup ester. Selain gugus ester juga terdapat gugus ikatan atom karbon dengan karbon dan gugus metil. Gugus metil akan dapat diidentifikasi pada bilangan gelombang 2960,56 $\mathrm{cm}^{-1}$. Gugus hidroksil yang teridentifikasi pada bilangan gelombang $3538,84 \mathrm{~cm}^{-1}$ diduga berasal dari sisa gliserol. Hal ini membuktikan bahwa di dalam sampel terdapat triasetin.

Gambar 4 menunjukkan tahap pencocokan hasil analisis FTIR produk triasetin dengan beberapa senyawa yang sejenis seperti triasetin standar, vinil alkohol, vinil asetat, 1,3-butanadiol diasetat, selulosa asetat dan etilen glikol. Pada Gambar 4, spektrum sampel terletak paling atas, diikuti dengan (dari atas ke bawah) triasetin standar dengan konsentrasi 99\% 1,3-butanadiol diasetat dengan konsentrasi $90 \%$, vinil asetat, selulosa asetat, dan etilen glikol diasetat 99\%. Pencocokan spektra inframerah produk reaksi menunjukkan kemiripan tertinggi dengan triasetin standar, yakni sebesar 81\%. Hal ini membuktikan bahwa reaksi yang dilaksanakan dalam penelitian ini berhasil memproduksi triasetin.

\section{Studi Pengaruh Temperatur}

Penelitian ini menggunakan variasi temperatur yang cukup tinggi, mengacu pada penelitian yang dilakukan oleh Reddy dkk. (2010). Penelitian tersebut memperoleh konversi $>30 \%$ pada temperatur $80{ }^{\circ} \mathrm{C}$, dengan konversi tertinggi tercapai pada temperatur $120{ }^{\circ} \mathrm{C}$ menggunakan katalis campuran Zirkonia. Untuk menghindari menguapnya reaktan asam asetat yang mempunyai titik didih $118{ }^{\circ} \mathrm{C}$, penelitian ini menggunakan pendingin balik, sehingga penguapan asam asetat dapat diminimalisasi meskipun temperatur reaksi mencapai $120{ }^{\circ} \mathrm{C}$. Hasil penelitian pada perbandingan mol pereaksi gliserol dengan asam asetat 1:3 dengan temperatur 80,90, 100, 110 dan 120 ${ }^{\circ} \mathrm{C}$ disajikan pada Gambar 5.

Gambar 5 menunjukkan terjadinya peningkatan konversi sejak menit nol sampai waktu 60 menit. Hal ini terjadi karena semakin lama waktu reaksi maka konversi semakin besar akibat kesempatan pereaksi untuk saling bertumbukan semakin besar (Levenspiel, 1999). Gambar 5 juga menunjukkan bahwa nilai konversi pada temperatur $80{ }^{\circ} \mathrm{C}$ hingga temperatur $120{ }^{\circ} \mathrm{C}$ mengalami kenaikan. Untuk reaksi kesetimbangan peningkatan temperatur reaksi akan menyebabkan laju reaksi meningkat baik reaksi ke arah produk (kanan) maupun reaksi ke kiri /balik. Peningkatan laju reaksi selama belum mencapai kondisi kesetimbangan maka laju reaksi ke arah produk lebih besar dibandingkan dengan laju reaksi ke arah reaktan/kiri.

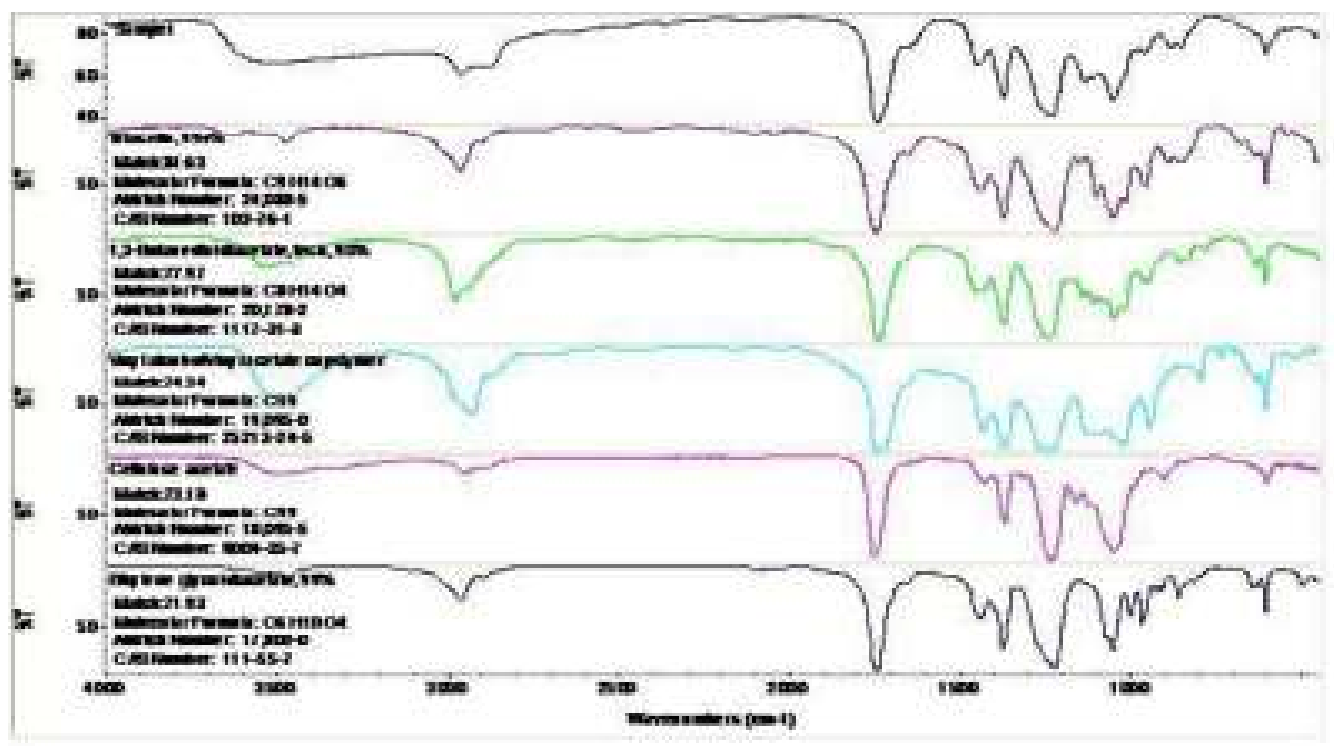

Gambar 4. Pencocokan hasil analisis FTIR produk triasetin 


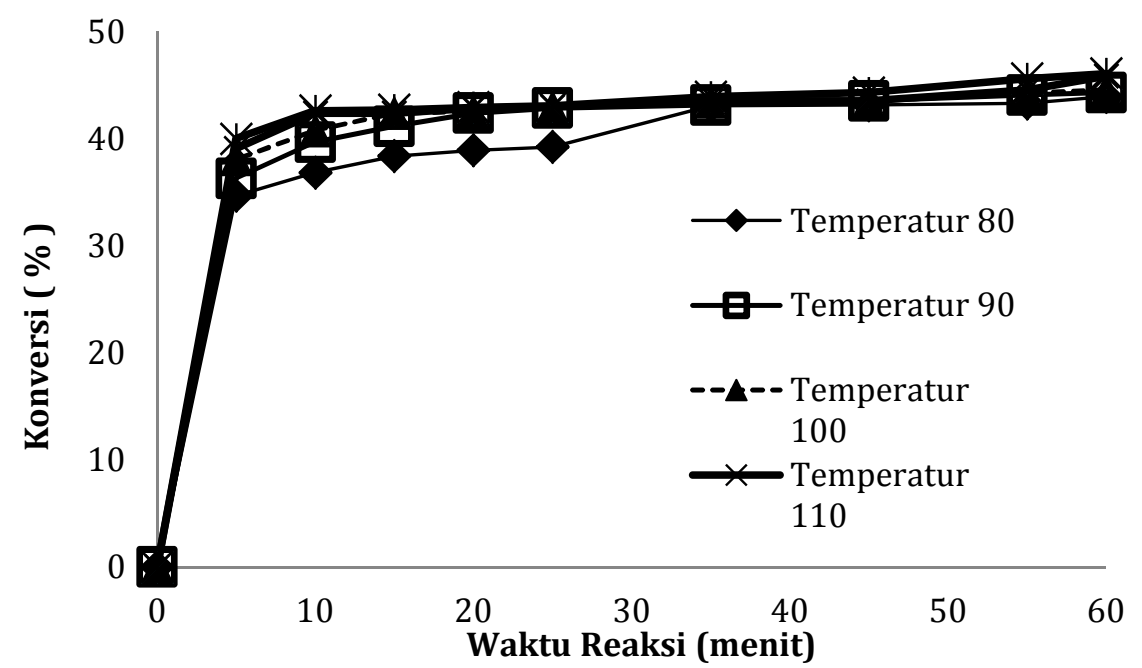

Gambar 5. Grafik hubungan temperatur reaksi dan konversi pada perbandingan mol pereaksi 1:3

Dengan demikian peningkatan temperatur reaksi hanya mempengaruhi laju reaksi yang ke arah produk/kanan. Hal ini sesuai dengan persamaan Arrhenius berikut:

$\mathrm{k}=\mathrm{A} \mathrm{e}^{\frac{\mathrm{E}_{\mathrm{A}}}{\mathrm{RT}}}$

Jika nilai temperatur reaksi semakin tinggi, maka kecepatan reaksi akan bertambah besar sehingga konversi yang diperoleh semakin besar pula. Konversi yang diperoleh masih terlalu kecil jika dibandingkan dengan penelitian yang telah ada (Ferreira dkk., 2009; Balaraju dkk., 2010; Nuryoto dkk., 2010; Reddy dkk., 2010; Ferreira dkk., 2011; Khayoon dan Hameed, 2011). Perbedaan nilai konversi yang diperoleh disebabkan oleh perbandingan reaktan yang digunakan sangat berbeda. Pada penelitian sebelumnya, menggunakan perbandingan reaktan minimal $1: 6$, sehingga reaktan yang digunakan sangat berlebihan dan reaksi menjadi reaksi searah.

\section{Pengaruh Perbandingan Reaktan}

Percobaan sintesis pada temperatur $120{ }^{\circ} \mathrm{C}$ dengan perbandingan mol pereaksi gliserol dengan asam asetat 1:3; 1:4; 1:5; 1:6; dan 1:7 menghasilkan nilai konversi seperti terlihat pada Gambar 6 .

Gambar 6 menunjukkan bahwa peningkatan perbandingan mol gliserol terhadap asam asetat dari 1:3 hingga 1:7 meningkatkan konversi. Hal ini disebabkan karena esterifikasi merupakan reaksi dapat balik, sehingga jika salah satu reaktan dibuat berlebih, maka reaksi akan bergeser ke arah kanan. Dengan reaksi bergeser ke arah kanan maka produk yang diperoleh juga semakin besar dan mengakibatkan konversi semakin besar pula (Levenspiel, 1999). Gambar 6 di atas dapat juga menunjukkan bahwa kondisi terbaik dihasilkan pada perbandingan mol pereaksi gliserol terhadap asam asetat 1:7 temperatur $120{ }^{\circ} \mathrm{C} 50$ menit, yakni dengan nilai konversi sebesar $67,6 \%$ dan selektivitas sebesar $25 \%$.

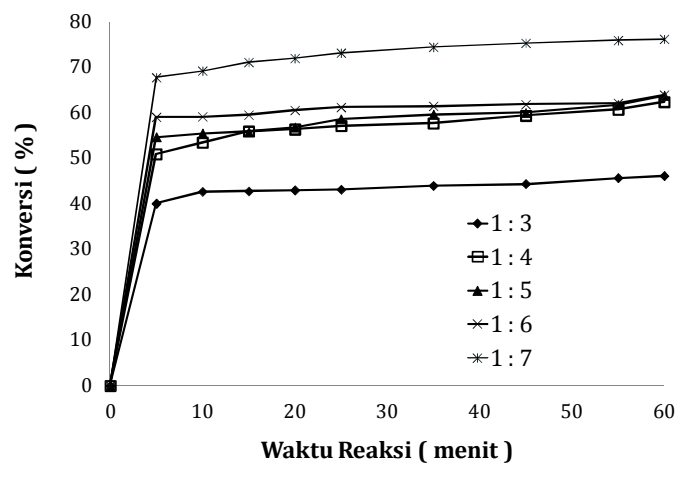

Gambar 6. Grafik hubungan perbandingan mol pereaksi dan konversi

Penelitian ini berhasil memperoleh konversi yang tinggi. Hal ini dapat dibandingkan dengan hasil penelitian terdahulu (Gelosa dkk., 2003; Ferreira dkk., 2009; Xiayuan dkk., 2009; Balaraju dkk, 2010; Jagadeeswaraiah dkk., 2010; Nuryoto dkk., 2010; Reddy dkk., 2010; Ferreira dkk., 2011; Khayoon dan Hameed, 2011) yang membutuhkan waktu reaksi cukup lama, yakni sekitar 4 jam, sementara penelitian ini membutuhkan waktu sekitar 50 menit. Dibandingkan dengan Ferreira dkk. (2009), 
penelitian ini menghasilkan konversi yang sama, namun dengan waktu yang lebih singkat, demikian juga selektivitas yang dihasilkan lebih besar jika dibandingkan dengan hasil-hasil penelitian di literatur. Penelitian Jagadeeswaraiah dkk. (2010), Xiaoyuan dkk. (2010), dan Ferreira dkk. (2011) diperoleh selektivitas sebesar 25\%.

\section{KESIMPULAN}

Gliserol dapat direaksikan dengan asam asetat membentuk triasetin dengan katalis asam sulfat. Peningkatan perbandingan reaktan dengan asam asetat akan meningkatkan konversi gliserol. Peningkatan temperatur operasi juga akan meningkatkan konversi gliserol. Produk triasetin yang terbanyak diperoleh pada perbandingan mol pereaksi gliserol dan asam asetat 1:7, temperatur $120{ }^{\circ} \mathrm{C}$ dan waktu 50 menit, dengan katalis asam sulfat 5\% (berat gliserol). Konversi gliserol yang diperoleh selama 1 jam sebesar 67,6323\% dengan selektivitas sebesar 25\%. Hasil penelitian dapat dikembangkan dalam upaya mengolah produk samping industri biodiesel menjadi produk yang lebih bermanfaat.

\section{DAFTAR PUSTAKA}

Balaraju, M.; Nikhitha, P.; Jagadeeswaraiah, K.; Srilatha, K.; Sai Prasad, P. S.; Lingaiah, N., Acetylation of glycerol to synthesize bioadditives over niobic acid supported tungstophoric acid catalysts, Fuel Processing Technology, 2010, 91(2), 249-253.

Ferreira, P.; Fonseca, I. M.; Ramos, A. M.; Vital, J.; Castanheiro, J. E., Esterification of glycerol with acetic acid over dodecamolybdophosphoric acid encaged in USY zeolite, Catalysis Comunications, 2009, 10(5), 481484.

Ferreira, P.; Fonseca, I. M.; Ramos, A. M.; Vital, J.; Castanheiro, J. E., Acetylation of glycerol over heteropolyacids supported on activated carbon, Catalysis Communications, 2011, 12(7), 573-576.

Gelosa, D.; Ramaioli, M.; Valente, G.; Morbidelli, M., Chromatographic reactors: esterification of glycerol with acetic acid using acidic polymeric resins, Industrial and Engineering Chemistry Research, 2003, 42(25), 6536-6544.

Rahmat, N.; Abdullah, A. Z.; dan Mohamed, A. R., Recent progress on innovative and potential technologies for glycerol transformation into fuel additives: A critical review, Renewable and Sustainable Energy Reviews, 2010, 14(3), 987-1000.

Jagadeeswaraiah, K.; Balaraju, M.; Prasad, P. S. S.; Lingaiah., N., Selective esterification of glycerol to bioadditives over heteropoly tungstate supported on Cs-containing zirconia catalysts, Applied Catalysis A: General, 2010, 386(1-2), 166-170.

Khayoon, M. S.; Hameed, B. H., Acetylation of glycerol to biofuel additives over sulfated activated carbon catalyst, Bioresource Technology, 2011, 102(19), 9229-9235.

Levenspiel, 0., Chemical Reaction Engineering $3^{\text {th }}$ edition; Wiley and Sons: New York, 1999.

Nuryoto; Sulistyo, H.; Rahayu, S. S.; Sutijan., Uji Performa Katalis Resin Penukar Ion untuk Pengolahan Hasil Samping Pembuatan Biodiesel Menjadi Triacetin, Prosiding Seminar Rekayasa Kimia dan Proses, 2010.

Pagliaro, M.; Michele, R., The Future of Glycerol: New Uses of a Versatile Raw Material; RSC Green Chemistry Book Series: Cambridge, UK, 2008.

Reddy, P. S.; Sudarsanam, P.; Raju, G.; Reddy, B. M., Synthesis of bio-additives: acetylation of glycerol over zirconia-based solid acid catalysts, Catalysis Communications, 2010, 11(15), 1224-1228.

Liao, X.; Zhu, Y.; Wang, S. G.; Li, Y., Producing triacetylglycerol with glycerol by two steps: esterification and acetylation, Fuel Processing Technology, 2009, 90(7-8), 988-993.

Vogel, A. I.; Jeffrey, G. H., Textbook of Quantitative Chemical Analysis $5^{\text {th }}$ edition; Longman Scientific and Technical: New York, 1989. 